\title{
The Mutual Influence in Gardening Art of Iran and Maverannachr of XV-XVI Centuries
}

\author{
Sadikova Sitora-Bonu \\ Ph.D Researcher of Samarkand State Architecture and Civil Engineering Institute, Uzbekistan
}

\begin{abstract}
Chingizid (XIII - XIV centuries), the Timurid (XIV-XVI centuries) and the Safavid (XV-XVII centuries) dynasties' cultures, architecture and garden art.
\end{abstract}

Keywords: Traditional Chor-Bag gardens, mutual influence, art, boulevard-Hiaban, ensemble of gardens.

\section{Introduction}

As in the era of the Achaemenid Dynasty (VI-IV b.c.e.), the Sassanid ( II-VII b.c.e.) and during the period under the Arabic Khalifat (VIII-X c.), the Samanid (X-XI c.), Mongols (XII-XIII c.), the Seljuk Dynasty (XIV-XVI c.), the Timurid Dynasty (XIV-XVI c.) and the Safavid Dynasty (XV-XVII c.) countries included in the territory of the Middle East were under the mutual influence.

Factual data on the contrary tell about the multiple-vector of the mutual influence of architectural cultures and styles of the Timurid's and Iranian dynasties. Let's look in detail on the mutual influence of Medieval Iran's and Maveranachr's gardening arts.

Chagatai, the son of Genghiz Khan (1227-1242), inherited the region included Bukhara, Samarkand, Iran and Uigur plains, created the dynasty of Mongolian monks, known as "Il-Khan" or deputy of Khan. Along with ruinous wars during his governance Il-Khan Khuledji (1256-1265) gathered the best poets, philosophers, musicians, manuscripts writers, architects and scientists in his palace. Thus he built a famous observatory for scientist -Nazir AtTusi.

The period under Il-Khan Makhmud Gazan (1295-1304) was named as the "Gold Age" period. In his new capital Tabriz he completed the construction of Moraih's observatory, built bridges, roads and numerous public buildings.

After Mahmud Gazan, Oljeitu Khodabandeh, the son of Arghun, also a descend of Mongol's governors in Iran, succeeded to the throne (1304-1316). In 1307 a construction of Sultan's mausoleum with relics of the Ali and Hussein Prophets on the south of Tabriz, which was planned by Oljeitu as a new capital, the center of Shi'ah' pilgrims was started. The huge sizes of the mausoleum expressed the power of the Mongolian Empire which extended from the Upper Euphrates till the boarders of India. In the plan of the construction the sizes of the mausoleum were $40 \times 60 \mathrm{~m}$, including an octangular space with a diameter of $24,5 \mathrm{~m}$, covered with a cupola with a height of $48 \mathrm{~m}$. The interior space with the main and diagonal axis had eight iwans and roundabout gallery for the ceremonial and cycling processions. Interior walls are florid by a gorgeous colored mosaic with a geometrical motive. However, this mausoleum did not become a relic of Shi'ah and turned into mausoleum of Sultan Oljeitu.

The building of Jami in Tabriz, that was started to build in 1310 and saved only the part of sanctum with aspic Mihrab till our days, is pointed as the colossal character of Mongol's architecture. With its dimensions, this mosque competed with a Palace of the Sasanian Dynasty in Ctesiphone. The fornication with a height of $36 \mathrm{~m}$ and with a diameter of $27 \mathrm{~m}$ covered the hall with a depth of $43 \mathrm{~m}$. Oblong court $200 \times 250 \mathrm{~m}$ included iwans with the plan sizes of $30 \times 65 \mathrm{~m}$ and with a height of $40 \mathrm{~m}$. You can guess about the enterprise of the project by looking at the kept part of the fornication, which is still dominated over the ground for 25 $\mathrm{m}$ with walls with a $10 \mathrm{~m}$ thickness in the basement.

In the beginning of 14 century (1308) in Natanz, between Koshan and Isfahan, Jami including Sheikh Abdas-Samad Isfahani mausoleum with four classical iwans was built. The decoration with many-colored mosaic all over the building's surface, including kufu inscriptions and also colored stalactites supporting the fornication became a famous practice by this time. The mausoleum of Imam Zade (1261 1307 ) - the Mongolian building in Varamin city is fretted too, and the floral motifs form arabesque.

At the end of XIV century on the territory of modern Iran the part of Central Asia and Afghanistan - raised a large state of Emir Timur (1369-1405). He established the capital in Samarkand and built it with a luxury. Under Emir Timur and his successors the art of Iran and Central Asia are tightly connected. Beautifying Samarkand and the town of his youth - Shahrisyabz, Emir Timur extensively engaged masters from Iran and Azerbaijan, and Central Asian architects made a significant impact on town planning culture of Iranian and Afghanian towns. "Samarkand in XIV$X V$ centuries was a trend-setter of architectural ideas: ordering of a planning, a construction of new roads among the complicated net of Samarkand, Herat and Isfahan streets, creating town's architectural ensembles, accentuated them with a color, making a gorgeous decoration of portals and cupolas with calaits and many other things, was an innovation of architects at the age of the Timurid's Dynasties"..[5] The confirmation of that fact is the construction of 14 gardens with magnificent names around Samarkand. All gardens were named according to their location or architectural decoration (illustration1): 


\section{International Journal of Science and Research (IJSR) \\ ISSN (Online): 2319-7064}

Index Copernicus Value (2013): 6.14 | Impact Factor (2014): 5.611

1. Bagi Nakhshi-Jeikhan ("World Ornament Garden")

2. Bagi Bekhisht ("Paradise Garden")

3. Bagi Emirzade Sheikhrukh ("Prince Sheikhrukh Garden")

4. Bagi Buldy ("Prosperity Garden")

5. Bagi Dilkhusha ("Heart Seduced Garden")

6. Bagi Shamal ("North Wind Garden")

7. Bagi Zagan ("Crows Garden")
8. Bagi Balyand ("High Garden")

9. Bagi Davlet Abad ("Place of Happy or Power residence Garden")

10. Bagi Chenar ("Chenars Garden")

11. Bagi Nau ("New Garden")

12. Bagi Jeikhan Numa ("Peace demonstrated Garden")

13. Bagi Maidan ("Square Garden")

14. Bagcha (the Garden) of Ulugh beg with Cheni-hana

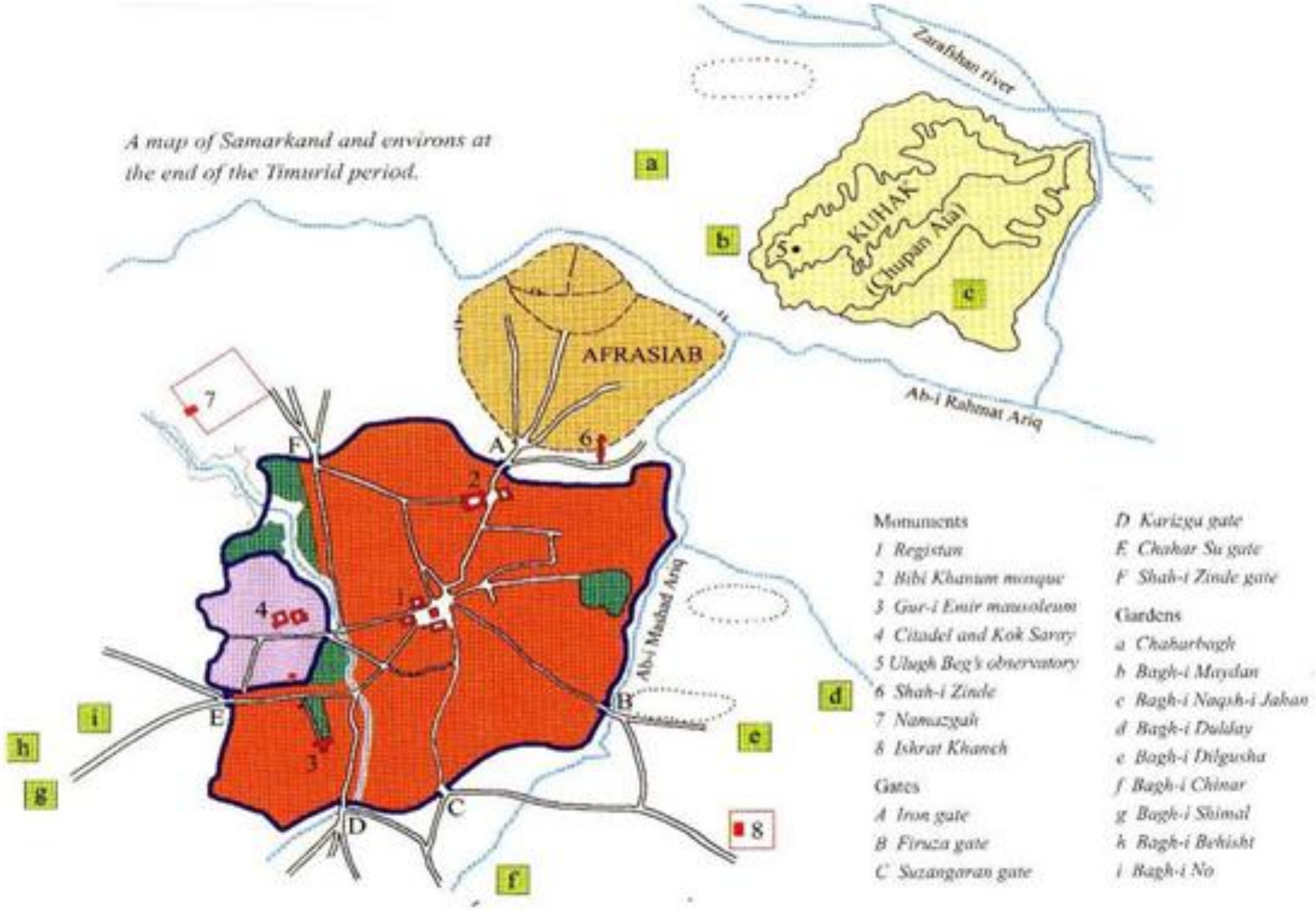

Illustration 1: The map of Samarkand and it's suburb at the end of the Timurid's Dynasty era.

The building of Isfahan Jami on the Maydani Kadim square, that was a center of the primary town is an outstanding example of the mutual influence of the cultures. Founded by the Abbasids in VIII-IX centuries, built by Sheick Malik in XI century, the Seljuks and Emir Timur in XIII-XIV it embodied the styles of the Arabian, Mongolian, Seljuk's and the Timurid's epochs. The main role was a creation of "Chor-Bag" garden and "Khiaban" connecting the NakshiJakhan and Abbas-Abad gardens of the Timurids in Isfahan. In particular under Amir Timur and the Timurids (XIV-XV) the style of Samarkand architecture expanded over the whole territory of country: in Bukhara, Shahrisyabz, Balkh, Herat, Merv, Mashhad, Nishapur, Isfahan, Koshan, Kerman, Natanz, Yazd, Turkestan and so on. This incredible "Golden Age" from 1360 till 1510 created a series of masterworks of universal importance. The Central Asian architects made a significant impact on the town planning culture of Iran in terms of the ordering the town planning, the construction of the new roads, the creating of the town's architectural ensembles where their importance in the town were marked with a color. It seems that all facts mentioned above, gave the base for N. Ardalan and L. Bakhtiyar - Iranian scientists in the area of the Islamic architecture, to menthion: that
"Motherland of Safavid Iran gardening style were Samarkand and Herat gardens of the Timirid dynesty".[1]

In its turn, Iran reached the highest peaks in the sphere of culture and architecture under the Safavid Dynasty within 200 years. In 1598 Sheikh Abbas returned the capital from Kazvin to Isfahan. (illustration 2) 


\section{International Journal of Science and Research (IJSR) \\ ISSN (Online): 2319-7064}

Index Copernicus Value (2013): 6.14 | Impact Factor (2014): 5.611

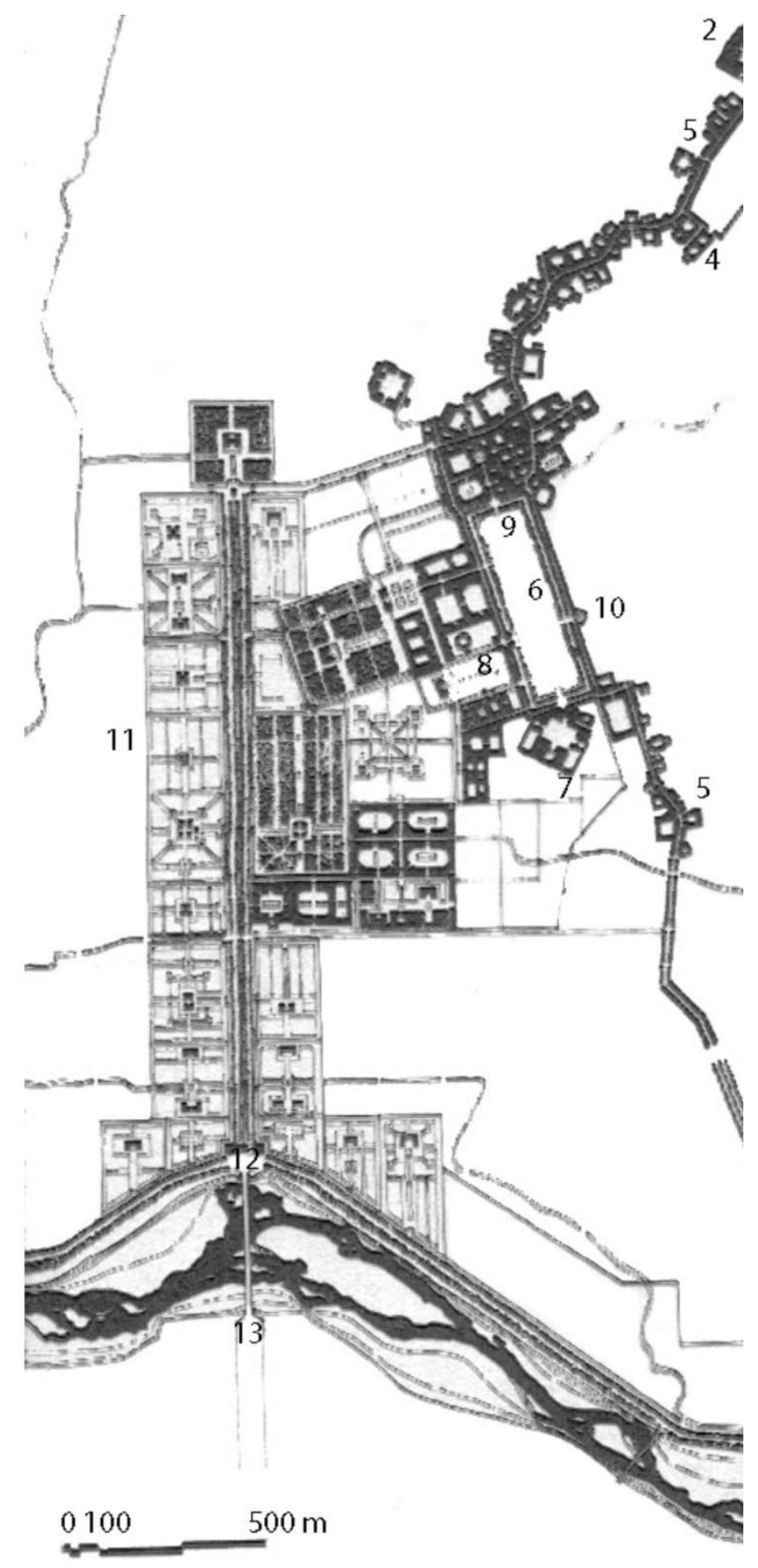

Composition form:

1. "Maydani Kadim" Square

2. Friday mosque

3. Quarters of old town

4. Ali's Minaret and Mosque

5. Bazaar (market)

6. "Maidany Sheikh" Square

7. Sheikh's mosque

8. Ali Kapu and new palace quarters

9. Entrance to bazaar (Kaissariya)

10. Lutfullah Mosque

11. Gardens

12. Shakhar Bagh

13. Allaverdi khan Bridge

14. Hoji Shakhar Bagh

15. Hoji Bridge

16. Zayandeh River
Illustration 2. The plan of Isfahan during Safavid Dynasty XVI century

He innovatively reconstructed this ancient city of Seljuk's, in a historically scale changed city's structure with new streets, squares and gardens, brought the unique town planning method by implementing the regular square planning into an irregular planning of central Asian town, developing the old city center from Maydani- Kadim for 1,5 $\mathrm{km}$ to the grand square of Maydani-Sheikh new center and in $0,5 \mathrm{~km}$ to the lined ensemble of Chor - Bag gardens spread for $1,65 \mathrm{~km}$ to the Zayendeh river and further for $3 \mathrm{~km}$ over the suburb.

This composition was originated in Central Asia and received a wide expansion under Amir Timur and the Timurid dynasty. Its name was Rubiya or Kytiya, from Arabic literally means "four-part" and such were the Shakhristans of Bukhara, Shakhrisyabz, Andizhan and Shakhrukhiya cities. Bailakan city in Azerbaijan and Herat city in Afghanistan were reconstructed according to the similar scheme in XIV-XV centuries.

Sheikh Abbas created a Maydani-Shakh new square (The King's Square), now is known as Maydani-Imam, between the new "Chor-bag" Khiaban and the old city by enlarging the old open space Nakshi- Jakhan, which was founded by Amir Timur as a place of camping-ground. By the example of lay-out the square (sizes $510 \times 165 \mathrm{~m}$ ), including the mosque of Sheikh, the mosque of Lutfullo, trading archads, bazaar and it was planned as a big caravans' gathering, military parades and sport competitions place. The six-floors Palace Ali Kapu (The Gates of Ali) with a face for the square built up during the age of Amir Timur and Sheikh Takhmas dominates at the entrance of Palace gardens.

Sheikh Abbas completed the belvedere (terrace), which is supported by tall wooden columns, the method is known now as a "talar". From this terrace, with a height of 33 meters, Sheikh could watch a Polo (Chavgan) games. The palace consists of audience rooms, music and dance rooms with shaped and emblazoned fretworks on the ceiling formed a mukarnas (stalactites).

In the gardens amazing with its beauty Chekhel Sutun pavilion was built, and its 20 columns, reflected in the water pond, gave the impression that there are not 20 columns but 40, that's why the name of this pavilion is "Forty columns".(Illustration 3)

In this magnificent audience room Sheikh sat solemnly on the throne in Aiwan decorated with mukarnas (stalactites) with an incrustation from mirrors shined with thousands of shades. The main boulevard - Khibian of the city - ChorBag leads from the Palace to the Zayendeh river. There is a tasteful bridge named as "Allah Verdi" across the river. Chinars and poplars, roses and jasmines are planted in several rows along the Khiaban. There were constructed five reservoirs for Chor Bag irrigation.

In spring fountains and flowers give the special charm to the gardens. The Khasht Bekhisht or "Eight Paradise" is the most beautiful among the pavilions built up along the 


\section{International Journal of Science and Research (IJSR) \\ ISSN (Online): 2319-7064}

Index Copernicus Value (2013): 6.14 | Impact Factor (2014): 5.611

garden. Under its wonderful cupola there is a fountain bringing the coolness. The walls of pavilion are painted.

The government of Sheikh Abbas I (1587-1629) brought to Iran the peace and prosperity it never had before. Sheikh extended patronage to the gardening, town planning and carpet art.

In the landscaping appearance of gardens' festoons connected with each other and with a city by Khiabans around Samarkand and Herat is the outstanding input of the Timurids in the town-planning art and the landscape architecture of the Middle East, also as an input of architects of Sheikh Abbas period in XVI c. in the creation of Maidani Sheikh ensemble and Shakhar Bag complex of Isfahan gardens, have received a great development in the gardens Baburid North India.

\section{References}

[1] N. Ardalan, L. Bakhtiar . «Sens of unity». The University of Chicago Press, Chicago-London, 1973, p.111

[2] Henri Stierlin. «Islamic art and architecture», p. 288289

[3] E.Clark . «The art of the Islamic garden». Translation from English - M.«Niola-Press», 2008. - p.208

[4] V.Ya. Kurbatov. «The world history of the landscape art. Gardens and Parks of the world».

[5] A.Regel . «The tasteful gardening and painterly gardens», St. Petersburg, 1896, p. 47

[6] Pore N. Ackerman Ph. «Gardens», SPA. T11. LondonNew York. 1939. p. 1427-1445

[7] SH.D. Askarov «A Region, a space, a city». 1990. p. 73.

[8] Isfahan. Iran Issue: The Architectural Review, Volume CLIX N.951 May 1976. c.280) 